\title{
Telemedicine sebagai Media Konsultasi Kesehatan di Masa Pandemic COVID 19 di Indonesia
}

\author{
Genny Gustina Sari, Welly Wirman \\ Jurusan Ilmu Komunikasi FISIP Universitas Riau \\ Kampus Bina Widya Panam KM 12,5 Pekanbaru Riau \\ E-mail: gennygustina@ lecture.unri.ac.id
}

DOI: https://doi.org/10.21107/ilkom.v15i1.10181

\begin{abstract}
ABSTRAK
Bidang kesehatan mengalami kemajuan pesat dengan mengadopsi internet dalam penerapannya, internet memudahkan pekerjaan dan memungkinkan terobosan baru dalam dunia kesehatan melalui e-health. Tulisan ini mencoba melihat bagaimana situs-situs e-health seperti Alodokter dan Halodoc menjadi media konsultasi kesehatan secara online bagi masyarakat. motif apa yang melatarbelakangi pasien memilih berkonsultasi online dan bagaimana masyarakat menaruh kepercayaan konsultasi tanpa tatap muka khsusunya selama masa pandemic COVID 19 dengan menggunakan teori fenomenologi Alferd Schutz yang menitikberatkan pada motif. Penelitian ini menggunakan metode kualitatif dengan pendekatan fenomenalogi. Teknik pengumpulan data melalui wawancara secara online dengan para pasien di aplikasi Alodokter dan Halodoc yang dilakukan dalam kurun waktu 5 bulan dengan total jumlah informan sebanyak 6 orang. Hasil penelitian menunjukkan Because to Motive seseorang melakukan konsultasi online adalah karena pandemic COVID 19 yang menimbulkan kekhawatiran dan ketakutan untuk melakukan konsultasi langsung dan karena penyakit yang dikonsultasikan dianggap pasien bukan penyakit yang serius. In Order to Motive pasien melakukan konsultasi kesehatan online adalah untuk mendapatkan informasi dan solusi dari penyakit yang diderita, untuk mendapatkan rekomendasi obat yang harus dikonsumsi atau Tindakan yang harus ditindaklanjuti serta untuk memperoleh ketenangan atas kecemasan yang dirasakan mengingat banyaknya keluhan yang dikonsultasikan mengacu pada pertanyaan tentang gejala COVID 19. Tingkat kepercayaan pasien kepada hasil diagnosis online menunjukkan bahwa umumnya pasien akan mempercayai hasil diagnosis untuk penyakit ringan, namun untuk diagnosis yang mengarahkan pasien menemui dokter ahli cenderung diabaikan pasien.
\end{abstract}

Kata kunci: $e$-health, konsultasi, media, COVID 19

\begin{abstract}
The health sector has experienced rapid progress with the adoption of the internet in its application, the internet makes work easier and allows new breakthroughs in the world of health through e-health. This paper tries to see how e-health sites such as Alodokter and Halodoc have become media for online health consultations for the public. What motives are behind patients choosing to consult online and how do people trust in face-to-face consultations especially during the COVID 19 pandemic using Alferd Schutz's phenomenological theory which focuses on motives. This study uses a qualitative method with a phenomenalogy approach. The technique of collecting data through online interviews with patients on the Alodokter and Halodoc applications was carried out within a period of 5 months with a total number of informants as many as 6 people. The results showed that someone doing an online consultation was due to
\end{abstract}

\section{Cite this as :}

Sari, Genny Gustina \& Welly Wirman (2021). Telemedicine sebagai Media Konsultasi Kesehatan di Masa Pandemic COVID 19 di Indonesia. Jurnal Komunikasi, 15(1), 43-54. doi: https://doi.org/10.21107/ilkom.v15i1.10181

Article History :

Received February, $14^{\text {th }}$ 2021, Acepted March, 13 2021 
the COVID 19 pandemic which caused concern and fear to do a direct consultation and because the disease being consulted was considered the patient was not a serious illness. In Order to Motivate patients to do online health consultations is to get information and solutions to their illness, to get recommendations for drugs to be consumed or actions that must be followed up and to get peace over the anxiety they feel given the many complaints consulted referring to questions about symptoms COVID 19. The level of patient confidence in online diagnosis results shows that generally patients will trust the diagnosis for minor illnesses, however, diagnoses that lead patients to see an expert doctor tend to be ignored by patients.

Keywords: e-health, consultations, media, COVID 19

\section{PENDAHULUAN}

Indonesia sebagai negara berkembang memang masih harus berjuang memperbaiki kualitas kesehatan masyarakat. Berdasarkan urutan peringkat Human Development Growth Index per 2010 Indonesia berada di posisi 111 selisih 9 peringkat dengan Palestina yang berada di urutan 101. Rasio dokter di Indonesia juga masih 1 berbanding 5.000 penduduk yang jauh tertinggal dari Malaysia yang berbanding 1:700 penduduk. Permasalahan ini disebabkan oleh tingginya minat masyarakat Indoensia berobat keluar negeri dibandingkan di Indonesia menunjukkan tingkat kepercayaan pasien pada dokter-dokter di Indonesia yang sangat rendah. Dalam tulisannya, Anwar mengutip penyataan ketua IDI yakni dalam setahun hampir 1 juta orang berobat keluar negeri dengan uang yang dibelanjakan sebesar 20 triliun (Anwar, 2013).

Sebelum tahun 1999 kita belum mengenal istilah $e$-health. Barulah setelah para pemimpin indutri dan perusahaan periklanan mengenalkan istilah e-health mengimbangi lahirnya e-commerce, e-bisnis dan lainnya. Dalam arti sempit e-health diartikan sebagai layanan kesehatan dan informasi yang disampaikan atau ditingkatkan melalui internet dan teknologi terkait. Sedangkan dalam arti luas, e-health bearti pengembangan keadaan pikiran, cara berpikir, sikap dan komitmen untuk jaringan, pemikiran global untuk meningkatkan perawatan kesehatan secara local, regional dan seluruh dunia dengan menggunakan teknologi informasi dan komunikasi. E-health diharapkan mampu menjawab tantangan baru era digital melalui 1) kemampuan konsumen untuk berinteraksi secara online (bisnis ke konsumen), 2) peningkatan transmisi data dari industry ke industry (bisnis ke bisnis), dan 3) terbukanya kemungkinan komunikasi peer to peer (konsumen ke konsumen) (Eysenbach, 2001).

Telemedicine adalah praktek kesehatan dengan memakai komunikasi audio, visual dan data, termasuk perawatan, diagnosis, konsultasi dan pengobatan serta pertukaran data medis dan diskusi ilmiah jarak jauh. Berdasarkan pengertian di atas, dapat kita pahami bahwa cakupan telemedicine cukup luas, meliputi penyediaan pelayanan kesehatan jarak jauh (termasuk klinis, pendidikan dan pelayanan administrasi), melalui transfer informasi (audio, video, grafik), dengan menggunakan perangkatperangkat telekomunikasi (audio-video interaktif dua arah, komputer, dan telemetri) dengan melibatkan dokter, pasien dan pihakpihak lain. Secara sederhana, telemedicine sesungguhnya telah diaplikasikan ketika terjadi diskusi antara dua dokter membicarakan masalah pasien lewat telepon (Jamil, Khairan, \& Fuad, 2015).

Komunikasi antara dokter dan pasien adalah komponen penting dalam proses penyembuhan pasien karena termasuk dalam memberikan pelayanan yang baik, ramah dan menenangkan justru meicu energi positif pasien untuk optimis akan kesembuhan penyakitnya. Empati yang diberikan dokter lewat komunikasi verbal dan nonverbal pada akhirnya akan menciptakan hubungan interpersonal yang baik (creating a good interpersonal relationship), pertukaran informasi (exchange of information), dan 
pengambilan keputusan medis (medical decision making) (Liansyah \& Kurniawan, 2015)

Situs atau website online yang menyediakan konsultasi kesehatan online menjadi salah satu trend yang lahir dari perkembangan teknologi komunikasi. Alodokter dan Halodoc merupakan beberapa diantara cukup banyaknya situs online yang cukup terkenal di Indonesia. Konsultasi kesehatan online didukung oleh pra dokterdokter yang memiliki latar belakang ilmu kesehatan yang mampu menganalisis dan mendiagnosis kondisi kesehatan pasiennya. Namun tidak bisa diabaikan, keberadaan situs konsultasi online ini juga bukan tanpa masalah, kesulitan dalam memfasilitasi perilaku dan memotivasi pasien tidak efektif. Kesulitan lain yang timbul dan cukup serius adalah informasi kesehatan yang disampaikan terkadang kuurang relevan sehingga beresiko menurunkan kulitas pelayanan dan kepercayaan pasien (Iqbal \& Husin, 2017). Pertanyaan selanjutnya adalah bagaimana seorang dokter mengdiagnosis penyakit pasien hanya lewat keluhan yang disampaikan (bukan yang ditampakkan) oleh pasien dan bagaimana pasien menaruh kepercayaan terhadap hasil diagnosis tersebut.

Factor personal yang membuat pasien menggunakan layanan $e$-health adalah karena adanya kesadaran bahwa kesehatan adalah asset penting yang harus dijaga dan keinginan untuk mencari informasi secara cepat dari sumber yang dianggap dapat dipercaya (Wahyuni \& Nurbojatmiko, 2017). Penelitian ini ingin melihat motif pasien menggunakan layanan konsultasi online pada situs kesehatan Alodoc dan Halodoc serta sejauh mana tingkat kepercayaan yang diberikan pasien kepada hasil diagnosis tersebut selama masa pandemic COVID 19.

Alodokter merupakan situs yang menyediakan informasi kesehatan di Indonesia yang membantu masyarakat untuk mengambil keputusan yang baik tentang kesehatan mereka. Konsep yang dibangun oleh situs ini selain menyediakan informasi tentang kesehatan juga menyediakan kesempatan pasien berkonsultasi langsung dengan para dokter-dokter professional. Perusahaan ini menjamin kekakuratan informasi yang disampaikan karena didasarkan riset ilmiah dan disunting secara seksama menyebabkan kepercayaan masyarakat semakin hari semakin tinggi (https://sepositif.com/kisah-sukses-nathanaelfaibis-pendiri-alodokter-com/ diakses 12 Januari 2021). Alodokter menyajikan 8 tema postingan yaitu; tubuh, fakta dan mitos, nutrisi, reproduksi dan kehamilan, menyusui, pertumbuhan dan perkembangan anak, tips kesehatan dan tanya jawab yang semua ditangani oleh para dokter professional (Arviani, 2020).

Halodoc merupakan perusahaan telekonsultasi kesehatan di Indonesia yang didirikan pada tahun 2016 oleh Jonathan Sudharta. Situs ini menyediakan layana berbicara dengan dokter, membeli obat serta akses untuk melakukan pemeriksaan laboratoium lewat smartphone. Jargon perusahaan ini adalah simplifying healthcare menghadirkan kemudahan dan layanan prima bagi masyarakat secara online selama 24 jam di

Indonesia

(https://www.halodoc.com/media diakses 12 Januari 2021). Dea Imarotunnisa Oktavia dalam tulisannya menyatakan bahwa kredibilitas Halodoc mempengaruhi kepercayaan konsumen lewat persepsi resiko, persepsi kemanfaatan, kualitas pelayan dan citra perusahaan yang dirasa sangat baik (Oktavia, 2020). Nyatanya konten dan akurasi merupakan variable yang paling mempengaruhi kepuasaan pengguna terhadap layanan yang diberikan oleh Halodoc (Izzati, 2020).

Pandemic COVID 19 turut berpengaruh pada minat masyarakat dalam menggunakan layanan konsultasi online ini. Penerapan Pembatasan Sosial Skala Besar (PSBB) membatasi masyyarakat untuk berkunjung ketempat umum terutama Rumah Sakit. Ketakutan masyarakat akan virus ini menyebabkan masyarakat enggan untuk berobat kerumah sakit, situs konsultasi online 
menjadi salah satu solusi yang cukup solutif. Ketua Ikatan Dokter Indonesia (IDI) daeng M. Faqih menyatakan bahwa layanan telemedis dapat membantu masyarakat yang ingin berkonsultasi mengenai masalah kesehatan yang tidak membutuhkan penanganan khusus. World Economic Forum mengungkapkan tiga manfaat layanan telemmedis; 1) layanan itu membuat tenega kesehatan bekerja lebih efektif dan produktif, 2) layanan konsultasi online bisa meningkatkan hasil klinis yang baik dan 3) telemedis bisa menurunkan biaya perawatan kesehatan dengan meningkatkan aksesibilitas dan produktivitas (https://lokadata.id/artikel/layanan-telemedisdiminati-pada-masa-pandemi-covid-19 diakses 12 Januari 2021).

Penulis melihat beberapa penelitian yang mencoba menganalisa pemanfaatan telemedicine selama masa pandemic seperti yang dilakukan oleh Rashid Bashshum (2020) dengan judul Telemedicine and the COVID19 Pandemic, Lessons for the Future, Ameet Doshi (2020) tentang Keep Calm and Log On: Telemedicine for COVID-19 Pandemic Response, serta penelitian Anthony Jnr. Bokolo (2021) dengan judul Application of telemedicine and eHealth technology for clinical services in response to COVID-19 pandemic sama sekali belum menyinggung mengenai motif pengguna memilih mengkonsultasikan kesehatannya secara online. Baik Bashshum, Doshi maupun Bokolo hanya menjabarkan manfaat dan penggunaan telemedicine selama pandemic dari sudut pandang kebermanfaatan dan efektivitasnya saja. Inilah yang kemudian membedakan penelitian mereka denga napa yang penulis lakukan. Penulis merasa manfaat, kepercayaan dan kepuasan konsumen menjadi dasar utama yang harus dibahas lebih mendalam.

Penelitian ini bertujuan untuk menggali secara personal alasan para pasien menggunakan situs konsultasi kesehatan online selama masa pandemic COVID 19 serta sejauh mana mereka menaruh kepercayaan terhadap hasil diagnosis tersebut. Pemilihan situs Alodokter dan Halodoc sebagai subjek penelitian karena dua situs ini dianggap sebagai situs telemedis pertama di Indonesia. Penelitian ini menggunakan metode fenomenologi sebagai landasan dalam mengumpulkan dan menganalisa data.

Penulis menggunakan teori Fenomenologi dari Alferd Schutz yang menitik beratkan motif pada dua aspek yaitu in-order motive dan because motive. Motif yang pertama adalah motif "sebab" (because of motive). Kemudian motif yang kedua adalah motif "tujuan" (in order to motive). Motif "sebab" adalah yang melatarbelakangi seseorang melakukan tindakan tertentu. Sedangkan motif "tujuan" adalah tujuan yang ingin dicapai oleh seseorang yang melakukan suatu tindakan tertentu. Schutz mengadaptasi pandangan Verstehen tentang pemahaman makna subjektif sama dengan penekanan fenomenologis yang menganalisis struktur makna pada individu dan gubungannya dengn struktur, atau individu dengan individu. Pengalaman dan asumsi dari makna bersama merupakan dasar yang ada dalam kehidupan social (Kuswarno, 2009). Fenomenologi sebagai metode tidak membahas mengenai siapa dan apa asumsi dasar yang dihasilkan. Sebagai metode, fenomenologi mencoba mengangkat sebuah realitas kedalam laporan penelitan tanpa menghilangkan esensi asli dari fenomena tersebut. Tingkat objektivitas peneliti untuk menjelaskan subjektivitas fenomena yang diamatinya menjadi kunci utama keberhasilan penerapan metode fenomenologi ini (Wirman \& Sari, 2019).

\section{METODE PENELITIAN}

Penelitian ini menggunakan metode penelitian kualitatif dengan pendekatan fenomenologi. Metode penelitian kualitatif deskriptif adalah suatu metode dalam meneliti status kelompok manusia, suatu objek, satu set kondisi, suatu pemikiran ataupun suatu kelas peristiwa pada masa sekarang (Moleong, 2017), (Sugiyono, 2012). Penulis menggunakan pendekatan fenomenologi, Untuk mengetahui alasan pasien memilih situs online Alodokter dan Halodoc dalam 
melakukan konsultasi kesehatan mereka selama masa pandemic COVID 19, penulis menggunakan pendekatan fenomenologi, dimana dalam pendekatan ini peneliti langsung meneliti sebuah kesadaran dari pengalaman (awareness of experience), yaitu keadaan yang memberikan sudut pandang pengalaman dari orang pertama (Kuswarno, 2009).

Subjek penelitian merupakan informan yang menjadi sumber dalam rangkaian penelitian. Informan adalah orang pada latar penelitian yang dimanfaatkan untuk memberi informasi tentang situasi dan kondisi latar penelitian (Moleong, 2017). Pemilihan subjek penelitian menggunakan teknik purposive dengan menentukan kriteria yaitu; 1) informan pernah menggunakan situs online Alodokter dan Halodoc selama masa pandemic, 2) pengguna melakukan konsultasi online selama kurang lebih 3 kali dengan asumsi informan sudah memahami bagaimana mekanisme kerja konsultasi online tersebut, 3) informan bersedia dihubungi secara personal dan intens selama penelitian. Selama bulan Juli hingga November 2020 penulis telah mewawancarai 6 orang yang dianggap mewakili dan menjawab pertanyaan dalam penelitian ini. Penulis menemukan informan dari nama-nama pasien yang mengajukan pertanyaan kemudian mencoba menelusuri melalui media social Intagram dan Facebook lalu mencocokkan dengan foto profile yang sama dengan yang digunakan di situs Alodokter atau Halodoc dan menghubungi via chat secara personal.

Table 1. Daftar Informan

\begin{tabular}{|clcl|}
\hline No & Inisial & Umur & \multicolumn{1}{c|}{ Pekerjaan } \\
\hline 1 & F & 34 Tahun & Guru Olahraga \\
\hline 2 & PP & 19 Tahun & Mahasiswa \\
\hline 3 & RW & 27 Tahum & Karyawan swasta \\
\hline 4 & RM & 34 Tahun & Ibu Rumah Tangga \\
\hline 5 & IA & 40 Tahun & Ibu Rumah Tangga \\
\hline 6 & BK & 23 Tahun & Karyawan Bank \\
\hline
\end{tabular}

Sumber: Olahan Penulis, 2020
Strategi pemilihan informan memang memakan waktu, namun penulis harus memastikan informan dalam penelitian ini memiliki tingkat kepercayaan yang cukup tinggi kepada penulis sehingga mereka bersedia memberikan informasi yang akurat dan apa adanya. Pada mulanya, penulis menemukan 12 orang pengguna Alodokter dan Halodoc untuk dijadikan informan, namun selama proses penelitian hanya 6 orang saja yang bersedia dan tetap konsisten memberikan informasi yang penulis butuhkan. 6 orang lainnya dianggap sebagai informan bias karena menolak untuk dijadikan informan, menolak menyampaikan informasi secara detail dan tidak konsisten dalam memberikan jawaban.

Adapun teknik pengumpulan data dilakukan melalui observasi dan wawancara mendalam. Observasi adalah proses pengumpulan data dengan cara peneliti turun langsung kelapangan untuk mengamati apa saja yang terjadi dilapangan. Teknik observasi memungkinkan peneliti untuk melihat, mencata dan terlibat langsung dengan aktivitas informan, hal ini memungkinkan peneliti mendapatkan data yang sebenarnya yang tajam dan pada suatu titik peneliti mampu melihat dan mengetahui makna dari perilaku yang tampak (Sugiyono, 2012). Saat melaksanakan observasi, penulis melakukan pendekatan secara personal melalui chat di akun media social para informan dan menanyakan kesediaan yang bersangkutan untuk menjadi informan penelitian.

Wawancara mendalam digunakan sebagai teknik pengumpulan data memalui penyampaian pertanyaan yang sifatnya umum hingga rinci dengan tujuan sebagai pendahuluan atau untuk menemukan datadata yang lebih mendalam. Teknik pengumpulan data ini berdasarkan daripada laporan tentang diri atau self-report, atau setidak-tidaknya pada pengetahuan atau keyakinan pribadi (Sugiyono, 2012). Komunikasi pada tahap awal yang telah penulis bangun dengan para informan menjadi dasar dalam Teknik wawancara mendalam. Adanya kedekatan yang dijalin sebelumnya 
membuat komunikasi antara penulis dengan informan sudah seperti teman sehingga para informan lebih terbuka dan leluasa memberikan informasi yang dibutuhkan.

\section{HASIL DAN PEMBAHASAN}

Kehadiran situs telemedicine menjadi solusi yang ditawarkan kepada masyarakat selama masa pandemic COVID 19. Ditengah kekahawtiran dan kecemasan yang meliputi masyarakat pada akhirnya turut mempengaruhi kesehatan yang menimbulkan banyaknya keluhan yang ditakutkan masyarakat sebagai gejala COVID 19. Situs Alodokter dan Halodoc menjadi sarana bagi para pasien untuk mengkonsultasikan kondisi kesehatan mereka secara online. Motif penggunaan menggunakan situs online tersebut beragam diantara para informan. Penulis menjabarkan menjadi because of motive dan in order to motive.

Motif adalah daasar dari sebuah Tindakan atau perilaku seseorang. Keputusan informan dalam menggunakan telemedicine dalam penelitian ini aplikasi Alodokter dan Halodoc menjadi menarik untuk didalami khususnya motif yang melatarbelakangi Tindakan tersebut. Penulis melihat efektivitas dan kredibilitas telemedicine akan dipengaruhi dari kepuasan pengguna terhadap akurasi informasi yang diterima. Jauh sebelum melihat efektivitas aplikasi serta tingkat kepuasan pengguna tentu kita perlu melihat motif apa yang melandasi perilaku tersebut.

\section{Because of Motive Melakukan Konsultasi Kesehatan Online}

Because of motive atau yang bisa juga disebut sebagai motif "sebab" merupakan alasan yang mendasari informan dalam penelitian ini untuk melakukan konsultasi kesehatan secara online dengan menggunakan situs telemedicine yang tersedia. Enam orang informan menyatakan selama masa pandemic tahun 2020 setidaknya mereka telah menggunakan situs telemedicine tersebut sebanyak 5 hingga 6 kali untuk mengkonsultasikan keluhan-keluhan kesehatan yang mereka atau keluarga mereka alami. Dari hasil wawancara yang penulis lakukan melalui media whatshap atau personal chat di Instagram setidaknya terdapat dua alasan utama yang melandasi penggunaan situs konsultasi kesehatan online Alodokter dan Halodoc.

Pandemic COVID 19 yang melanda dunia dengan tingkat penyebaran yang cukup tinggi dan angka kematian yang terus bertambah membuat kepanikan, ketakutan dan rasa cemas menjadi pemandangan yang kita temui setiap hari. Rumah sakit menjadi tempat yang dijadikan rujukan bagi para penderita COVID 19 namun disisi lain menjadi tempat yang sangat dihindari masyarakat dikarenakan asumsi Rumah Sakit adalah tempat dimana virus Corona tersebut banyak ditemukan. Hal inilah yang menjadi alasan pertama dan utama penggunaaan situs konsultasi kesehatan online menjadi pilihan para informan seperti yang disampaikan IA seorang ibu Rumah tangga:

“. kami sekeluarga ngga berani mbak
kerumah sakit, sementara keluhan-
keluhan seperti pusing, demam atau pilek
itu kan sebelumnya hal yang lumrah ya..
Cuma kan corona itu juga gejalanya jadi
konsultasi aja secara online dulu..." (Wawancara Tanggal 4 Agustus 2020).

Pernyataan yang hampir sama disampaikan oleh informan RW yang berprofesi sebagai karyawan di sebuah perusahaan swasta yang menyatakan:

\footnotetext{
“.. saya masih harus keluar rumah mbak.. cari makan, sementara dibulan April dan Mei itu baru-baru ngeh kita sama ni virus.. khawatir mbak kalo harus ke Rumah sakit, disana banyak pasien COVID.. kita g tahu kan gimana penyebarannya tau-tau ntar kenak.. makanya saya lebih milih konsultasi online aja.. mungkin karena stress dengan kondisi ini jadi parno gitu.. capek dikit udah takut aja kenak COVID.. jadi saya tanyain aja di Alodokter atau
} 
Halodoc itu.." (Wawancara tanggal 18

Agustus 2020).

Perasaan cemas, takut dan khawatir yang timbul karena pandemic nyatanya membuat masyarakat menjadi paranoid dengan kondisi kesehatan mereka. Keluhankeluhan seperti demam, flu, kelelahan yang sebelumnya dianggap sebagai keluhan biasa dan lumrah selama masa pandemic menjadi momok menakutkan karena adanya kemiripan dengan gejala COVID 19. Informan dalam penelitian ini menyampaikan bahwa permasalahan kesehatan yang dikeluhkan memang lebih banyak dan focus pada keluhan-keluhan yang dianggap mirip dengan gejala COVID 19.

“.. pastinya tentang gejala demam, bedanya demam biasa ama demam COVID itu apa? Kalo meriang atau kelelahan atau sakit tenggorokan aja gitu mbak.. saya tanyain.. karena parno mbak.. malah ada yang kabarnya tanpa gejala kena COVID, saya makin ngga berani ke Rumah Sakit dan mending konsul online aja"(wawancara dengan informan BK tanggal 1 September 2020).

Alasan yang kedua mengapa informan dalam penelitian ini lebih memilih konsultasi kesehatan secara online adalah karena keluhan yang disampaikan cenderung bukan keluhan yang berat sehingga mereka beranggapan keluhan tersebut akan mendapatkan jawaban dengan cepat. Di beberapa kasus khususnya keluhan tentang gejala COVID, pasien biasanya akan dikirimkan artikel atau pertanyaan-pertanyaan yang dianggap mirip dan telah dijawab para dokter sebelumnya. Bagi para informan, informasi yang diberikan sangat membantu menjawab permasalahan mereka.

\footnotetext{
“..kan gejalanya kayak misalnya bersin seharian itu kok sering biasanya ngga.. apa itu gejala corona gitu mbak.. atau pilek yang sampai ngga bisa ngebauin sesuatu itu yang gimana? Kan pilek emang ngga terlalu bisa ngebauin ya... nanya gitu-gitu aja paling mbak.. ngga yang ampe keluhan berat, kalo yang berat-berat ya pastinya langsung ke Rumah sakit mau
}

ngga mau..." (wawancara dengan PP

Tanggal 18 Agustus 2020).

Adanya informasi-insformasi yang telah dirangkum dan disampaikan kepada pasien jika memiliki indikasi kesamaan pertanyaan menjadikan situs konsultasi online dianggap sangat membantu menjawab kegelisahan masyarakat, karena terkadang informasi-informasi yang disampaikan tidak hanya menjawab pertanyaan mereka secara spesifik namun juga menjawab pertanyaanpertanyaan lain yang memiliki kesamaan sehingga pasien secara tidak langsung mendapat wawasan baru tentang penyebaran dan bahaya COVID 19 itu sendiri.

“... waktu itu saya agak pilek mbak, saya
seharian bersin-bersin berapa kali ya..
lupa.. tapi sering mbak..pas nanyain itu
di Aloddokter saya dikirimin banyak
banget pertanyaan-pertanyaan yang
mirip jadi bisa membantu saya sekali
ditambah lagi informasi-informasi lain
yang disampaikan wahhh... Saya jadi
ngga perlu nanya-nanya lagi kan..”
(wawancara dengan informanF
tanggal 4 Agustus 2020).

Because of motive para pasien dalam hal ini informan penelitian didasarkan pada kecemasan dan ketakutan yang timbul akibat pandemic COVID 19 sehingga jenis keluhan yang disampaikan juga terkait dengan gejalagejala COVID 19 yang dirasakan pasien yang sebelum pandemic dianggap sebagai gejala flu atau demam biasa saja. Informasi yang mereka terima dari hasil konsultasi kesehatan online tersebut nyatanya memberikan rasa nyaman, tenang dan lega kepada pasien yang diselimuti ketakutan dan kecemasan terkena virus Covid 19. Pada dasarnya penyebab para informan melakukan konsultasi kesehatan online adalah untuk mencari solusi akan kepanikan yang dirasakan selama pandemic. Simpang siur informasi yang berkembang mengenai COVID, ketidakjelasan solusi dan Langkah yang bisa diambil membuat masyarakat kebingungan, kesulitan untuk mempercayai informasi mana yang memuat kebenaran. Dengan melaksanakan konsultasi kesehatan online, para informan sebenarnya 
sedang berupaya menangkan diri dan mencari solusi dengan informasi yang mereka anggap lebih jelas, akurat dan dapat dipercaya terkait COVID 19.

\section{In Order to Motive Melakukan Konsultasi Kesehatan Online}

In order to motive adalah motif "tujuan" yang mengarah pada apa yang sebenarnya mereka harapkan dari tindakan yang dilakukan. Penggunaan situs konsultasi kesehatan online melalui situs Alodokter dan Halodoc yang digunakan sebagai alternatif selama masa pandemic tentunya bukan tanpa alasan, adanya solusi yang disampaikan, rekomendasi obat-obatan yang aman dan bisa dikonsumsi, ketenangan dan rasa aman yang diharapkan menjadi tujuan penggunaan situs telemedicine ini.

Seperti yang telah disampaikan di atas, keluhan-keluhan kesehatan yang dianggap pasien sebagai keluhan kecil nyatanya juga menjadi gejala-gejala awal penderita COVID 19. Informan mengharapkan, konsultasi kesehatan online yang dilakukan dapat memberikan mereka informasi dan solusi untuk menangani keluhan tersebut. Selain diagnosis yang disampaikan, nyatanya situs Alodokter dan halodoc juga menyediakan informasi-informasi lainnya terkait keluhan pasien. Salah satu menu pilihan yang menarik banyak minat pengguna adalah menu tanya jawab. Menu tanya jawab biasanya berisi listlist pertanyaan yang cukup sering dilontarkan pengguna. Selama pandemic COVID 19, menu tanya jawab banyak diisi oleh pertanyaan-pertanyaan seputar gejala dan cara menanggulangi COVID 19.

\footnotetext{
“... tentunya saya ngarepin solusi ya mbak.. ngapain nyampain keluhan kalo ngga ada solusi, nah.. saya tuh jadi tahu harus ngapain kalo gini.. kalo gitu.. apa aja yang harus dikonsumsi untuk menjaga daya tahan tubuh, bagaimana tata cara kalo mesti keluar? Apa yang harus atau ngga boleh dikerjakan.. gitu mbak.. solutif sih menurut saya.." (wawancara dengan
} RM tanggal 7 September 2020).

Solusi dan informasi
disampaikan selama konsultasi on
dirasakan oleh pasien bukan dari mes
penjawab, karena pada kondisi tertent
mereka bisa berinteraksi dan bertanya leb
detail dan rinci kepada dokter
mendiagnosis keluhan mereka. Hal
membuat para pasien merasa seolah-
telah atau sedang berkonsultasi lang
dengan pasien sehingga jawaban
diberikan cukup melegakan.
“.. kalau kita masih mau bertanya bisa
kan mbak.. bisa lebih spesifik nanti
dijawab langsung sama dokternya, nah
jadi berasa kayak konsul langsung di
rumah sakit.. jadi ngerasa informasi dan
diagnosisinya itu beneran kayak
dokternya ngomong ke kita mbak buka
mesin..dan emang kalo untuk
pertaanyaan yang rinci itu dokternya
kan yang jawab ya mbak?" (wawancara
dengan BK tanggal 25 September
2020).

Tujuan lain yang menjadi motif informan menggunakan situs konsultasi kesehatan online adalah karena ada rekomendasi obat-obatan yang bisa dan aman dikonsumsi tanpa resep dokter, selain itu jika dirasakan cukup serius, para dokter akan menyarankan pasien untuk menemui atau berkonsultasi dengan dokter spesialis di situs tersebut.

“... enaknya mbak.. kita tuh dijelasin
obat apa yang aman yang bisa
dikonsumsi tanpa rerep dokter jadi
bisa beli di apotek kan.. trus misalnya
waktu itu saya agak sesak nafas pas
tahu temen saya positif COVID 19,
saya disarakan konsul ke dokter
spesialis.. hmm ngga asal jawab aja
mbak, kalo ngga ada solusi di dokter
umum misalnya, kita diarahkan ke
dokter spesialis.. bisa cepat bisa milih
dokter pula..” (wawancara dengan F
tanggal 2 Oktober 2020).

Pada akhirnya, tujuan utama yang menjadi motif para pasien menggunakan situs konsultasi kesehatan online ini adalah karena keinginan dan dorongan untuk mendapatkan ketenangan dan kenyamanan. Perlunya rasa 
aman yang dipastikan dengan diagnosis dokter menjadi jaminan tersendiri bagi para pasien bahwa mereka sehat dan tidak terdampak COVID 19.

\begin{abstract}
“.. saya sih mbak, pengen dapet jawaban yang bisa bikin saya plong... daripada saya bimbang, cemas dan ragu saya nanyain ama orang-orang mending nanya ama dokter.. biar secara online tapi kan mereka dokterdokter hebat ya mbak.. ya pasti udah bener jawabannya makanya saya lega.. “ ( wawancara dengan IA tanggal 26 Agustus 2020).
\end{abstract}

Pernyataan serupa juga disampaikan informan BK yang mengaku bahwa selama masa pandemic kecemasan dan tingkat kewaspadaan akan gejala sekecil apapun yang dirasakan membuatnya membuutuhkan jawaban dari ahlinya, dengan menggunakan situs konsultasi kesehatan online BK merasa jawaban yang diberikan memberikan ketenangan.

\section{“.. selama COVID ini mbak... ngga cuma saya aja tapi mungkin hamper semua orang jadi parno sama gejala sekecil apapun yang dirasakan. Jadi setiap saya merasa sedikit aja ngga beres ama badan apalagi setellah saya dari luar rumah, saya konsul aja di situs online itu, kapan saja, dimana saja dan hemat waktu dijawab sama dokter pula.. hhmmm saya jadi tenang dan lega mbak.." (wawancara dengan BK tanggal 1 September 2020).}

Informasi dan solusi yang didapatkan oleh pasiesn setelah malakukan konsultasi online pada akhirnya mendatangkan rasa tenang dan nyaman bagi para pasien. Keluhan-keluhan yang dianggap ringan juga bisa mendapatkan rekomendasi obat atau penanganan dari para dokter yang tersedia di situs konsultasi kesehatan online Alodokter maupuan Halodoc. Penulis melihat situs ini adalah salah satu bentuk pertolongan pertama bagi masyarakat untuk mendapatkan informasi seputar COVID 19 dan infromasi kesehatan lainnya, dan yang juga tidak kalah pentingnya adalah sumber informasi adalah para dokter yang memiliki kredibilitas dan keahlian yang sudah terjamin sehingga kebenaran infromasi yang disampaikan dianggap jauh lebih bisa dipertanggung jawabkan. Motif penggunaan situs konsultasi kessehatan online pada akhoirnya adalah sebuah otonom bagi para pasien, menggunakan atau tiddak menggunakan. Tentu saja kelebihan diikuti dengan kekurangan namun penelitian ini membatasi diri hanya membahas pada wilayah motif dan sejauh mana tingkat kepercayaan yang diberikan pasien terhadap para dokter dan hasil diagnosis yang dikemukakan.

\section{Tingkat Kepercayaan Pasien Terhadap Hasil Diagnosis Kesehatan Online}

Berbicara mengenai tingkat kepercayaan tentunya kita berbicara mengenai sejauh mana informasi yang disampaikan oleh para dokter di situs konsultasi kesehatan online mampu meyakinkan pasien dan mengubah perilaku mereka. Melalui wawancara mendalam penulis mencoba melihat dan menganalisis tingkat kepercayaan pasien tersebut dari kedalaman atau kekuatan diagnosis dalam mengubah perilaku dan sikap pasien. Apa yang disampaikan oleh Dea Imoratunnisa Oktavia dalam penelitiannya tentang pengaruh kredibilitas perusahaan terhadap kepercayaan konsumen pada penggunaan aplikasi kesehatan Halodoc menunjukkan bahwa sebanyak $43 \%$ kepercayaan konsumen ditentukan oleh kredibilitas perusahaan dan informasi yang disampaikan.

Penulis melihat ada dua hal yang menarik dari tingkat kepercayaan terhadap hasil diagnosis dokter kepada pasien di situs konsultasi kesehatan online tersebut; pertama jika hasil diagnosis yang diberikan tidak menunjukkan indikasi kearah mengkhawatirkan artinya tidak membutuhkan konsultasi atau tindaklanjut kea rah yang lebih spesifik seperti diarahkan konsultasi dengan dokter ahli atau disarankan melakukan pemeriksaan lab, pada umumnya informan 
dalam penelitian ini akan mempercayainya. Selain itu pasien juga menerapkan informasi dan saran yang dianjurkan dokter dalam kehidupan sehari-hari seperti misalnya tata cara dan jenis masker yang sebaiknya digunakan, vitamin apa yang sebaiknya dikonsumsi atau tempat-tempat seperti apa yang sebaiknya dihindari serta menerapkan protocol kesehatan yang lebih baik dan benar.

\begin{abstract}
“ ..selagi hasil diagnosisnya ngga berbahaya ya alhamdulillah yak an mbak, saya menerapkan aja apa yang disarankan misalnya memilih jenis masker, selalu bawa hand sanitizer dan juga vitamin... bagi say aitu malah membuat saya semakin tenang dan nyaman" (wawancara dengan RW tanggal 7 Oktober 2020).
\end{abstract}

Namun hal yang tidak kalah menarik yang penulis temukan adalah Ketika hasil diagnosis menyarankan pasien untuk menindaklanjutinya dengan berkonsultasi dengan dosen spesialis atau mengarahkan pasien untuk melakukan pengecekan laboratoriuum dan menemui dokter di kota masing-masing, pasien cenderung mengabaikannya. Pasien merasa informasi atau diagnosis yang sifatnya serius tidak mungkin dihasilkan lewat konsultasi secara online. Pasien juga mengaku takut dengan hasil lab dan takut menerima kenyataan jika ternyata mereka memiliki Riwayat penyakit tertentu atau didiagnosis menderita sebuah penyakit yang butuh penanganan dokter spesialis.

\begin{abstract}
“.. waktu itu saya menanyakan kondisi ayah saya karena beliau sesak nafas sudah 3 hari dan memang punya Riwayat penyakit asma, tetapi setelah membaca hasil diagnosis dokter yang nyutuh ke dokter spesialis dan pemeriksaan lab, kita sekeluarga jadi ketakutan dan mempertanyakan apa iya lewat diskusi kata-kata aja bisa tahu penyakit yang berat-berat? Ya udah akhirnya kita ngga dengerin saran atau diagnosisnya mbak.." (wawancara dengan IA tanggal 7 Oktover 2020).
\end{abstract}

Hasil analisa penulis melihat bahwa tingkat kepercayaan pasien tidak ditentukan atas siapa dokternya, karena para pasien atau infroman dalam penelitian ini mempercayai kredibiltas para dokter yang ada di situs konsultasi online Alodokter atau Halodoc. Tingkat kepercayaan pasien didasarkan atas besar kecilnya resiko yang ditimbulkan oleh diagnosis para dokter. Pasien cenderung mempercayai hal-hal yang ingin dipercayainya sebagai sebuah kebenaran dan diluar dari itu dianggap salah.

\section{PENUTUP}

Penelitian ini menghasilkan
kesimpulan bahwa; Motif seseorang menggunakan situs konsultasi kesehatan online didalam penelitian ini adalah situs Alodokter dan Halodoc terbagi menjadi dua yaitu because of motive dimana kondisi pandemic COVID 19 membuat pasien terlalu takut dan cemas untuk melakukan konsultasi tatap muka dan berkunjung ke rumah sakit, alasan kedua adalah karean keluhan dianggap bukanlah jenis yang berat sehingga pasien merasa melakukan konsultasi kesehatan online adalah hal praktis dan efisien. Motif yang kedua yaitu in order to motive dimana tujuan pasien melakukan konsultasi kesehatan online adalah karena ingin mendapatkan informasi dan solusi atas keluhan yang disampaikan, tujuan selanjutnya adalah karena adanya informasi tambahan, rekomendasi jenis vitamin atau obat yang sebaiknya dikonsumsi hingga rekomendasi untuk mengikuti konsultasi lenjutan ke dokter spesialis dan sebagainya sedangkan tujuan terakhir adalah untuk mencari ketenangan dan kenyamanan atas kekhawatiran dari gejalagejala yang dirasakan menyerupai gejala COVID. Tingkat kepercayaan pasien tidak didasarkan pada kredibilitas dokter melainkan pada hasil diagnosis yang disampaikan. Jika hasil diagnosis tidak menganjurkan tindak lanjut yang lebih serius, para pasien akan mempercayai dan mengikuti saran yang disampaikan para dokter, namun jika hasil konsultasi merujuk pada pemeriksaan laboratorium atau melakukan konsultasi tatap muka dengan dokter justru ditolak dan 
dianggap tidak valid kebenarannya.

\section{DAFTAR PUSTAKA}

Adinda, Havivi Rizky. 2020. Kepuasan dan Barrier Pengguna Layanan Aplikasi telemedicine pada Masa Pandemi COVID-19 di Indonesia. Skripsi Fakultas kedokteran Universitas Brawijaya. https://repository.unsri.ac.id/39440/

Arviani, Heidy. \& Roziana Febrianita. 2020. Komunikasi E-Helath di Post Instagram: Analsis Isi Alodokter. MetaCommunication; Jurnal Ilmu Komunikasi Vol 5 No 1 Hal 1-12.

Anwar, A. (2013). Aspek Hukum Penggunaan Telemedicine. In FIKI 2013.

Bashshur, Rashid. Charles R. Doarn, Julio M Frenk \& Joseph C Kvedar. 2020. atelemedicine and The COVID 19 Pandemic, Lessons for The Future.Marry Ann Liebert.Inc. telemedicine and E-Health. Volume 26 No 5 Hal 1-3.

B. Ilham Ramadhan, and T. Pradekso. 2020. Hubungan Antara Terpaan Iklan Aplikasi Halodoc Dan Terpaan Persuasi Reference Group Dengan Minat Untuk Menggunakan Aplikasi Halodoc Sebagai Sarana Konsultasi Dengan Dokter. Interaksi Online, vol. 9, no. 1, Hal. 130-140.

Bokolo, A.J. 2021. Application of telemedicine and eHealth technology for clinical services in response to COVID-19 pandemic. Health

Technol. 11, 359-366. https://doi.org/10.1007/s12553-02000516-4

C. N. Mangkunegara, F. Azzahro and P. W. Handayani. 2018. Analysis of Factors Affecting User's Intention in Using Mobile Health Application: A Case
Study of Halodoc. International Conference on Advanced Computer Science and Information Systems (ICACSIS), 2018, pp. 87-92, doi: 10.1109/ICACSIS.2018.8618174.

Doshi, Ameet. Yonatan Platt, John R Dressen, Benji K Mathews \& Jerome C Siy. 2020. Keep Calm and Log On; Telemedicine for COVID 19 Pandemic Response. Journal of Hospital Medicine Volume 15 No 5 Hal 302304

Eysenbach, G. (2001). What is e-health? Journal of Medical Internet Research, 3(2), $1-5$. https://doi.org/10.2196/jmir.3.2.e20

Iqbal, Muhammad \& Husin.2017. Analisis Perbandingan Kualitas dan Fasilitas WEB Konsultasi Kesehatan Dengan Pendekatan Pieces Framework. Jurnal Mikrotil Vol 7 No 2 Desember 2017 (Hal 62-70).

Izzati, Vaya Annisa \& Yuki Firmanto. Analisis Kepuasan Pengguna Aplikasi kesehatan Halodoc melalui model End User Computing Satisfaction Selama masa Pandemi Covid 19. Jurnal IlmiahMahasiswa FEB, Volume 9 No 2 Hal 1-16.

Jamil, M., Khairan, A., \& Fuad, A. (2015). Implementasi Aplikasi Telemedicine Berbasis Jejaring Sosial dengan Pemanfaatan Teknologi Cloud Computing. Jurnal Edukasi dan Penelitian Informatika (JEPIN), 1(1). https://doi.org/10.26418/jp.v1i1.9930

Liansyah, Tita Menawati \& Hendra Kurniawan. 2015. Pentingnya Komunikasi Dalam Pelayanan Kesehatan Primer. Jurnal Kedokteran Syiah Kuala Vol 15 No 2 Agustus 2015 ( Hal 120-124).

Lubis, Zidni Imanurrohmah. 2020. Analisis Kualitatif Penggunaan Telemedicine 
sebagai Solusi Pelayanan Kesehatan di Indonesia pada Masa Pandemik COVID-19. Physiotherapy and Health Science - PhysioHS, Volume 2 Nomor 2 Hal 76-82.1

Kuswarno, E. (2009). Fenomenologi. Bandung: Widya Padjajaran.

Moleong, L. J. (2017). Metodologi Penelitian Kualitatif (Edisi Revisi). In $P T$. Remaja Rosda Karya (hal. 424).

Oktavia, Dea Imarotunnisa. Fortuna Zain Hamid \& Ni Made Widhi. 2020. Pengaruh Kredibilitas Perusahaan Terhadap Kepercayaan Konsumen Pada Penggunaan Aplikasi Kesehatan Halodoc. Seminar Nasional Terapan Riset Inovatif (SENTRINOV) ke-6 Volume 6 No 2. Hal 239-245.
R. Wahyuni and Nurbojatmiko. 2017. Explaining acceptance of e-health services: An extension of TAM and health belief model approach. 2017 5th International Conference on Cyber and IT Service Management (CITSM), Denpasar, Indonesia, 2017, pp. 1-7, doi: 10.1109/CITSM.2017.8089239.

Sugiyono. (2012). Metode Penelitian Kuantitatif, Kualitatif dan $\mathrm{R}$ \& D.Bandung:Alfabeta. Metode Penelitian Kuantitatif, Kualitatif dan $R \quad \& \quad$ D.Bandung:Alfabeta. https://doi.org/10.1017/CBO9781107 $\underline{415324.004}$

Wirman, Welly. \& Genny Gustina Sari. 2019. Fenomenologi Dalam Perspektif Ilmu Komunikasi. Riau : CV. Asa Riau. 